\title{
Model calculations of the effects of present and future emissions of air pollutants from shipping in the Baltic Sea and the North Sea
}

\author{
J. E. Jonson ${ }^{1}$, J. P. Jalkanen ${ }^{2}$, L. Johansson ${ }^{2}$, M. Gauss ${ }^{1}$, and H. A. C. Denier van der Gon ${ }^{3}$ \\ ${ }^{1}$ Norwegian Meteorological Institute, Oslo, Norway \\ ${ }^{2}$ Finnish Meteorological Institute, Helsinki, Finland \\ ${ }^{3}$ TNO, Princetonlaan 6, 3584 CB Utrecht, the Netherlands
}

Correspondence to: J. E. Jonson (j.e.jonson@met.no)

Received: 4 July 2014 - Published in Atmos. Chem. Phys. Discuss.: 27 August 2014

Revised: 5 December 2014 - Accepted: 20 December 2014 - Published: 22 January 2015

\begin{abstract}
Land-based emissions of air pollutants in Europe have steadily decreased over the past two decades, and this decrease is expected to continue. Within the same time span emissions from shipping have increased in EU ports and in the Baltic Sea and the North Sea, defined as SECAs (sulfur emission control areas), although recently sulfur emissions, and subsequently particle emissions, have decreased. The maximum allowed sulfur content in marine fuels in EU ports is now $0.1 \%$, as required by the European Union sulfur directive. In the SECAs the maximum fuel content of sulfur is currently $1 \%$ (the global average is about $2.4 \%$ ). This will be reduced to $0.1 \%$ from 2015, following the new International Maritime Organization (IMO) rules.

In order to assess the effects of ship emissions in and around the Baltic Sea and the North Sea, regional model calculations with the EMEP air pollution model have been made on a $1 / 4^{\circ}$ longitude $\times 1 / 8^{\circ}$ latitude resolution, using ship emissions in the Baltic Sea and the North Sea that are based on accurate ship positioning data. The effects on depositions and air pollution and the resulting number of years of life lost (YOLLs) have been calculated by comparing model calculations with and without ship emissions in the two sea areas. In 2010 stricter regulations for sulfur emissions were implemented in the two sea areas, reducing the maximum sulfur content allowed in marine fuels from 1.5 to $1 \%$. In addition ships were required to use fuels with $0.1 \%$ sulfur in EU harbours. The calculations have been made with emissions representative of 2009 and 2011, i.e. before and after the implementation of the stricter controls on sulfur emissions from 2010. The calculations with present emissions show that per person, an additional $0.1-0.2$ years of
\end{abstract}

life lost is estimated in areas close to the major ship tracks with current emission levels. Comparisons of model calculations with emissions before and after the implementation of stricter emission control on sulfur show a general decrease in calculated particle concentration. At the same time, however, an increase in ship activity has resulted in higher emissions of other components, and subsequently air concentrations, in particular of $\mathrm{NO}_{\mathrm{x}}$, especially in and around several major ports.

Additional model calculations have been made with landbased and ship emissions representative of year 2030. Following a decrease in emissions from all sectors, air quality is expected to improve, and depositions to be reduced. Particles from shipping are expected to decrease as a result of emission controls in the SECAs. Further controls of $\mathrm{NO}_{\mathrm{x}}$ emissions from shipping are not decided, and calculations are presented with and without such controls.

\section{Introduction}

Maritime transport is an important sector in Europe that enables trade and contacts between all the European nations. It ensures the security of supply of energy, food and commodities and provides the main vehicle for European imports and exports to the rest of the world. Compared to other modes of transport such as trucks and air freight, shipping is far more energy efficient. Almost $90 \%$ of the EU external freight trade is seaborne. Short sea shipping represents $40 \%$ of intra-EU exchanges in terms of ton-kilometres. (http: //ec.europa.eu/transport/modes/maritime/index_en.htm.) 
During the last two decades emissions of air pollutants from land-based sources have been substantially reduced over Europe. Emissions of $\mathrm{NO}_{\mathrm{x}}, \mathrm{CO}$ and NMVOC (nonmethane volatile organic carbon) have been reduced by about $50 \%$, and $\mathrm{SO}_{\mathrm{x}}$ emissions have been reduced by about $75 \%$ (Gauss et al., 2013). There are however large differences in the emission reductions between individual countries. As a result of the reductions in emissions, harmful effects of air pollution to the environment such as acidification and eutrophication, and health effects from particles and elevated ground level ozone events have been substantially reduced.

In the same time span modest regulations have been implemented for emissions from international sea shipping. Both the North Sea and the Baltic Sea are defined by IMO (International Maritime Organization) as SECAs (sulfur emission control areas). The most significant policy decisions affecting $\mathrm{SO}_{\mathrm{x}}$ and $\mathrm{PM}$ emitted from ships are the revision IMO MARPOL Annex VI $\mathrm{SO}_{\mathrm{x}}$ emission control area requirements and the EU sulfur directive. The former restricts the marine fuel sulfur content in SECAs to $1.0 \%$ as of July 2010 whereas the latter requires ships to use fuel with $0.1 \%$ sulfur in harbour areas from January 2010. Further reductions to $0.1 \%$ are mandatory in SECAs from January 2015. The Baltic Sea and the North Sea were accepted as SECAs in 2006 and 2007 respectively. Prior to July 2010 the maximum allowed sulfur content in SECAs was $1.5 \%$, as opposed to the global average of about $2.4 \%$ (IMO, 2010). Fuel sulfur reduction has a significant impact on emitted particulate matter (PM) and $\mathrm{SO}_{2}$, a precursor for PM. Particulate matter is commonly associated to detrimental effects on human health.

In sea areas outside the SECAs sulfur emissions have continued to increase. From 2020 the sulfur content in marine fuels outside SECAs should be reduced to $0.5 \%$ globally, but depending on the outcome of a review to be concluded in 2018 as to the availability of the required fuel oil, this date could be deferred to 2025. However, EU sulfur directive obliges ship owners to use $0.5 \%$ fuel in non-SECA EU sea areas starting from 1 January 2020 regardless of the outcome of the IMO review.

$\mathrm{SO}_{\mathrm{x}}$ and PM emissions from North Sea and Baltic Sea shipping are decreasing, but it is noteworthy that there may be some components of PM from shipping that are not affected by the fuel sulfur content. Thus the percentage decrease in PM emissions is not as large as for $\mathrm{SO}_{\mathrm{x}}$. The policy changes alone are not the only reason for the decrease of emitted pollutants. Also the recent decrease in overall economic activity has had an impact on ship emissions. The strong increase in the number of AIS transceivers installed in small vessels may have had some impact on estimated ship emissions.

For other species there has been a steady increase in the emissions in all sea areas around Europe in the last two decades. For $\mathrm{NO}_{\mathrm{x}}$ IMO Tier I and Tier II limits apply globally, regardless of whether or not ECAs for $\mathrm{NO}_{\mathrm{x}}$ will be established. The TIER I and TIER II requirements on new ships (or for major modifications on existing ships) were implemented in year 2000 and 2011 respectively. Tier I emission standards are up to $10 \%$ stricter than for ships built before year 2000, and Tier II standards are up to $15 \%$ stricter than Tier I, resulting in moderate reductions in $\mathrm{NO}_{\mathrm{x}}$ emissions. The Tier standards are described in IMO (2007). The efficiency increase and Tier II $\mathrm{NO}_{\mathrm{x}}$ limit together outweigh the moderate traffic growth (Kalli et al., 2013).

Future projections were made in accordance with Kalli et al. (2013). In their work, old vessels are replaced with new ones at the end of their lifecycle. In this approach, the new vessel to be introduced in the fleet will comply with future legislation (NECA - nitrogen emission control area - or no NECA as defined in the scenarios) but will not undergo liquid fuels to gaseous fuels transformation. All existing vessels known to use liquefied natural gas (LNG) will continue to do so even when they are replaced with new vessels in the scenarios. The share of LNG may however increase as there are additional LNG infrastructure projects under construction, and more are planned in the future.

Defining a NECA for both the Baltic Sea and the North Sea will help to reduce the emissions of $\mathrm{NO}_{\mathrm{x}}$ by as much as $80 \%$ from Tier I level on new ships. The Baltic Sea and the North Sea countries have already taken the first steps towards NECA but the decision regarding the formal submission of NECA IMO applications for the two sea areas will ultimately be political. Recent information (66th IMO MEPC meeting, March 2014) from IMO indicates that the entry date for NECAs, if implemented, will be left to the applicants to decide. The year 2016 is no longer strictly defined as an entry date, but some flexibility is allowed. The lower $\mathrm{NO}_{\mathrm{x}}$-emitting new engines installed on new ships will gradually replace old engines, but because of the long lifetime of ships, complete fleet renewal with Tier III compliant ships is not expected until about 30 years after the NECA entry date (Kalli et al., 2013).

Currently NECAs exist only along the North American coastline. The North American NECA was adopted in 2010, entered into force in 2011, and the implementation began in 2012. The implementation of the Caribbean NECA (Costa Rica and US Virgin Islands) began in 1 January 2014.

Several previous model calculations of the effects of ship emissions have been made both on global as well as regional scales. On a global scale both the climate effects and air pollution have been studied (Corbett et al., 1999, 2007; Endresen et al., 2003; Eyring et al., 2007; Fuglestvedt et al., 2010). In addition several regional studies have addressed the regional impacts of ship emissions in Europe (Jonson et al., 2000, 2009; Andersson et al., 2007; Brandt et al., 2013). Tuovinen et al. (2013) looked at the effect of increased shipping in the Arctic sea-lanes on nitrogen deposition and ozone uptake by vegetation. The assessment of the environmental and health benefits of a nitrogen emission control area in the North Sea (Hammingh et al., 2012) was an impact assessment commissioned by the coastal countries around the 
North Sea in support of the decision-making process concerning the possible application to the IMO to designate the North Sea as a NECA. The regional studies point to ship emissions as a major source of air pollution in Europe, in particular in coastal, often densely populated, areas.

Brandt et al. (2013) looked at the effects of air pollution from international shipping on air pollution and health on Northern Hemisphere scale to regional northern European scales. They calculate a $36 \%$ reduction in health-related external costs from between the years 2000 and 2020 as a result of emission reductions in the North Sea and the Baltic Sea. Within the same time frame, health-related external costs will increase in Europe as a whole due to an expected increase in ship traffic.

The novelty of this study is the use of high temporal and spatial resolution emission data, based on precise positioning data, for 2009 and 2011, i.e. before and after the revision of the EU sulfur directive and the IMO regulation of 2010. In addition, a future scenario has been investigated to look at changes to be expected with and without further regulation. The following section describes the experimental setup, while Sect. 3 describes results for the present-day situation as well as the future.

\section{EMEP model runs - model setup}

When calculating the effects of present and future emissions of air pollutants we have used the EMEP chemistry transport model (Simpson et al., 2012), version rv4beta20, hereafter referred to as the EMEP model. The EMEP model can be run on a wide range of scales, and for global to local applications. In this study the model is run on a regional European domain with an approximate $14 \mathrm{~km}\left(1 / 4^{\circ}\right.$ longitude $\times 1 / 8^{\circ}$ latitude) resolution. In the vertical, the model extends from ground level to $100 \mathrm{hPa}$ (tropopause or higher). Lateral boundary concentrations are provided by a combination of measurements and global model results. For ozone the lateral boundary concentrations are based on ozone climatology scaled by measurements from the clean sector at Mace Head, Ireland, unaffected by European emissions. A detailed description of the model can be found in Simpson et al. (2012) and references therein. The meteorological data for 2010 are from ECMWF (European Centre for Medium-Range Weather Forecasts). The EMEP model is available as open source code. The latest version can be obtained from https://wiki.met.no/emep/ page1/unimodopensource2011. The EMEP model is regularly evaluated against measurements in the EMEP annual reports, see http://emep.int/mscw/mscw_publications.html. Model calculations with the EMEP model are included in several recent publications comparing model results with measurements and calculations with other models (Jonson et al., 2010; Colette et al., 2011, 2012; Angelbratt et al., 2011).
The meteorological year 2010 was used in all the model calculations. The 2010 winter was colder and dryer than normal north of the Alps, and the cold weather returned towards the end of the year. The summer was very warm, in particular in Russia extending into the Baltic Sea (Maier et al., 2011). The warm summer resulted in higher than normal ozone levels around the Baltic Sea (Fagerli et al., 2012). The cold and dry winter resulted in $\mathrm{PM}_{2.5}$ and $\mathrm{PM}_{10}$ concentrations somewhat higher than expected from the long-term trend alone (Tsyro et al., 2012).

\subsection{Present and future emissions}

With the exception of ship emissions in the Baltic Sea and the North Sea the emissions of air pollutants are based on the EC4MACS Interim Assessment of "Greenhouse gases and air pollutants in the European Union: baseline projections up to 2030" (Amann et al., 2012). The emissions include both land-based emissions and emissions from international shipping. Here we are using year 2010 emissions to represent present conditions, and year 2030 for future projections. The gridding of the emission data was done in the EU FP7 project TRANSPHORM http://www.transphorm.eu. Ship emissions in the Baltic Sea and the North Sea are described below.

\subsubsection{Ship emissions in the Baltic Sea and the North Sea}

The emissions for the Baltic Sea and the North Sea areas were obtained with the Ship Traffic Emission Assessment Model (STEAM) (Jalkanen et al., 2009, 2012). In this model actual ship movements of individual ships collected from the national Automatic Identification System (AIS) base station networks are used. Combined with the characteristics of each ship and engine type, the emissions from each individual ship could then be calculated. The emission modelling is based on over 550 (2009) and 600 (2011) million automatic updates of vessel positions.

The model requires as input a detailed technical specification of all fuel-consuming systems onboard and other relevant technical details for all ships considered. Such technical specifications were therefore collected from various sources and archived for over 45000 ships. The data from IHS Fairplay (2012) constituted the most significant source. The STEAM model is then used to combine the AIS-based information with the detailed technical knowledge of the individual ships. The model then evaluates instantaneous fuel consumption and emissions of $\mathrm{NO}_{\mathrm{x}}, \mathrm{SO}_{\mathrm{x}}, \mathrm{CO}, \mathrm{CO}_{2}$ and PM. The IHS Fairplay database queries mostly cover vessels which have an IMO registry number. The database can be searched with a Mobile Maritime Service Identity (MMSI) number too. However, in more than $90 \%$ of the cases MMSI queries do not produce a valid response because there is no obligation for small vessels to register in these databases, especially if they operate in national waters. Often small vessel 


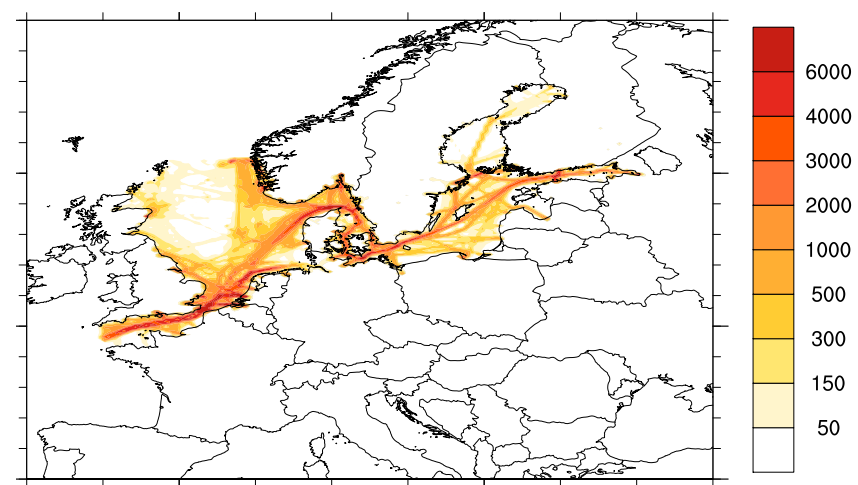

Figure 1. Ship emissions of $\mathrm{SO}_{\mathrm{x}}\left(\mathrm{mg} \mathrm{m}^{-2}\right)$ in the Baltic Sea and the North Sea in 2009.

particulars in STEAM are not known and default values need to be used when engine power levels are predicted. Obviously, this will lead to deteriorated performance of the emission model if compared to the quality of predictions for large vessels where engine data are more readily available.

The temporal dimension of emissions is retained, and daily updates of ship emissions were provided for air quality studies. The emissions were allocated to a geographical grid of approximately $0.03^{\circ} \times 0.06^{\circ}$ longitude latitude. Emissions are calculated for the years 2009 and 2011 to assess the impacts of already agreed policy options (SECA, EU sulfur directive).

Daily (or finer) emissions reflect ship operational differences caused by ice conditions, meteorological conditions etc., which will differ between years. The traffic pattern changes caused by the meteorological phenomena were included, but the impact of these on vessel power requirement to maintain a specific speed was not included in this study. Thus, the impact of weather as a source of additional fuel consumption was omitted. In this study we have compared the effects of emissions from 2009 and 2011, in addition to future projections. As none of these years coincide with the meteorological year (2010) used for the model runs, we have aggregated the emissions to monthly totals in the approximate $14 \mathrm{~km}$ model grid so that day-to-day operational fluctuations will cancel out. The total emissions in both sea areas are listed in Table 1 for the years 2009 and 2011, along with the projections for 2030 . The geographical distribution of the emissions is illustrated by the $\mathrm{SO}_{\mathrm{x}}$ emissions for year 2009 in Fig. 1. High emissions are in particular seen along the main shipping routes in the North Sea (and in particular in the English Channel), and also in the Baltic Sea. Note that sulfur emissions are reduced significantly from 2009 to 2011 as a result of stricter regulations. Emissions of other species are stable or increase slightly. Emissions of organic and elemental carbon and ash also increase as they are assumed to be unaffected by the fuel type (Johansson et al., 2013). In reality, different amounts of ash in distillate $(0.01 \mathrm{w} \%)$ and residual fuels $(0.07 \mathrm{w}-\%)$ are allowed as indicated by marine fuel standard (ISO 8127:2010; Chevron, 2012). In STEAM, the ash emission factor is $0.06 \mathrm{~g} \mathrm{kWh}^{-1}$ which corresponds to $0.03-0.04 \%$ (by mass) depending on engine-specific fuel oil consumption. The values used in STEAM for ash emission factors are similar to the results recently reported by Moldanova et al. (2013). More details of emission factors of PM components can be found in Jalkanen et al. (2012).

The fuel mix used in 2011 was estimated as $74 \%$ of residual and $26 \%$ as distillates, based on the engine properties and the fuel consumption of currently operational vessels in the study area. The future adoption rate of LNG as ship fuel is difficult to predict, but it is expected to grow significantly in the future, especially if new emission control areas for $\mathrm{NO}_{\mathrm{x}}$ are to be established. However, the NECA declaration of both the Baltic Sea and the North Sea is uncertain because it requires political consensus and the effective dates of new NECAs are yet to be defined. We have applied the 2011 fuel mix until 2015 after which a shift towards distillate fuels is expected, whereas the LNG share of marine fuels is held at 2011 level. This will have a slight impact on PM reduction prediction because it is likely that the adoption of LNG reduces PM more than the use of distillate fuels.

The Baltic Sea and North Sea ship emissions for 2030 are based on projections from Kalli et al. (2013) and are listed in Table 1 . The emissions are calculated by scaling the gridded 2009 emissions by the expected overall changes in emissions from 2009 to 2030 for the two sea areas as calculated by Kalli et al. (2013), taking into account changes in regulations, fleet renewal rates (in particular affecting $\mathrm{NO}_{\mathrm{x}}$ emissions, as Tier II are replacing Tier I) and expected changes in traffic volumes and ship efficiency.

Kalli et al. (2013) report bulk emissions for particles, including sulfate, OC, EC and ash. Here we assume that sulfate emissions between 2009 and 2030 will be reduced with the same rate as for $\mathrm{SO}_{2}$. As a result the corresponding percentage reductions in OC, EC and ash emissions are smaller than the reductions in total particle emissions estimated by Kalli et al. (2013) in order to match their estimate of total particle emissions in 2030.

It is uncertain when, or if, the two areas will be designated as NECAs. If so, ships built after NECA designation date will be Tier III compliant. As the designation of NECAs is still uncertain, $\mathrm{NO}_{\mathrm{x}}$ emissions for year 2030 are listed with and without a NECA, assuming an entry date of 2016. A complete fleet renewal is slow, and can be expected about 30 years from the NECA entry date. In the 2030 NECA scenario roughly half of the fleet conforms to Tier III $\mathrm{NO}_{\mathrm{x}}$ emission levels whereas the other half still consists of Tier I/II ships.

The implementation of the NECA may be delayed, as agreed in the 66th meeting of the IMO MEPC. A delay will result in higher $2030 \mathrm{NO}_{\mathrm{x}}$ emissions in the NECA than indicated in Table 1. 
Table 1. Emissions from shipping in the Baltic (BS) and North (NS) seas in $\mathrm{Gg} \mathrm{yr}^{-1}$. $\mathrm{SO}_{\mathrm{x}}$ emissions as $\mathrm{SO}_{2}$ and $\mathrm{NO}_{\mathrm{x}}$ emissions as $\mathrm{NO}_{2}$.

\begin{tabular}{l|rr|rr|rr|rr|rr|rr}
\hline & \multicolumn{2}{|c|}{$\mathrm{SO}_{\mathrm{x}}$} & \multicolumn{2}{|c|}{$\mathrm{NO}_{\mathrm{x}}$} & \multicolumn{2}{c|}{$\mathrm{SO} 4$} & \multicolumn{2}{c|}{ EC } & \multicolumn{2}{c|}{ OC } & \multicolumn{2}{c}{ Ash } \\
& $\mathrm{BS}$ & $\mathrm{NS}$ & $\mathrm{BS}$ & $\mathrm{NS}$ & $\mathrm{BS}$ & $\mathrm{NS}$ & $\mathrm{BS}$ & $\mathrm{NS}$ & $\mathrm{BS}$ & $\mathrm{NS}$ & $\mathrm{BS}$ & $\mathrm{NS}$ \\
\hline 2009 & 90 & 230 & 314 & 662 & 7.7 & 19.7 & 2.3 & 3.8 & 5.5 & 9.6 & 1.6 & 2.8 \\
2011 & 80 & 155 & 337 & 677 & 6.8 & 13.2 & 2.2 & 4.2 & 5.6 & 10.8 & 1.6 & 3.1 \\
2030 no NECA & 8 & 21 & 293 & 642 & 0.7 & 1.8 & 1.5 & 2.5 & 3.7 & 6.4 & 1.1 & 1.9 \\
2030 NECA & 8 & 21 & 217 & 457 & 0.7 & 1.8 & 1.5 & 2.5 & 3.7 & 6.4 & 1.1 & 1.9 \\
\hline
\end{tabular}

\section{Model results}

In order to calculate the effects of ship emissions in the Baltic Sea and the North Sea, several model runs have been made with the EMEP model. A first set of model runs has been made comparing model runs excluding the 2009 ship emissions in the North Sea and the Baltic Sea to a reference model run that included all emissions.

A second set of model runs has been made to look at the effects of the changes in ship emissions from 2009 to 2011. The main motivation for this is to see the effects of the decrease in the maximum sulfur content in marine fuels from 1.5 to $1 \%$ effective from 1 July 2010.

A third set of model runs has been made to assess the impact of projected future (2030) emissions from shipping in the Baltic Sea and the North Sea. Calculations for 2030 are made with and without the effects of future NECA regulations.

\subsection{Present situation}

Figure 2 shows the annually averaged concentrations of $\mathrm{PM}_{10}, \mathrm{PM}_{2.5}$ and daily maximum ozone. Also shown is the total deposition (wet and dry) of nitrogen from the reference model run.

Concentrations of PM largely reflect the emissions, with high PM levels throughout much of Europe. Of particular interest here are the high PM levels in the coastal regions around the North Sea and the English Channel and (to a lesser extent) the Baltic Sea. The EU annual limit values of $40 \mu \mathrm{g} \mathrm{m}^{-3}$ for $\mathrm{PM}_{10}$ and $25 \mu \mathrm{g} \mathrm{m}^{-3}$ for $\mathrm{PM}_{2.5}$ are not exceeded in the calculations. However, the WHO guidelines of 20 and $10 \mu \mathrm{g} \mathrm{m}^{-3}$ for annually averaged $\mathrm{PM}_{10}$ and $\mathrm{PM}_{2.5}$, respectively, are exceeded in limited parts of the model domain, including also areas/cities along the coast of the Baltic Sea and the North Seas.

In Fig. 3 the YOLLs (years of lives lost), calculated based on the $2010 \mathrm{PM}_{2.5}$ levels, are shown. YOLL is the average statistical loss in life expectancy of the population above the age of 30 due to exposure to $\mathrm{PM}_{2.5}$ concentrations. The calculations of YOLL are based on the RAINS methodology (Amann et al., 2004). A risk factor of $6 \%$ change in mortality hazards per $10 \mu \mathrm{g} \mathrm{m}^{-3}$ annual average change in $\mathrm{PM}_{2.5}$ as recommended by WHO (WMO, 2006) is used. The Norwegian Meteorological Institute applied these dose response re- lationships in the calculations made for the EuroDelta project (http://aqm.jrc.ec.europa.eu/eurodelta/). Of particular relevance to this paper are the regions along the southern coastlines of the two sea areas with calculated YOLLs per person of 0.2 years or more. The accumulated YOLLs per country (in thousands), as listed in Table 2, is the total number of statistical life years lost over the lifetime of the population above the age of 30 for selected countries adjacent to the two sea areas. The accumulated YOLL per country is calculated as the product of YOLL per person and the population in the individual grid cells, and then summed up for the individual countries. As an example we calculate about 18 million YOLL for Poland, which over a population of about 40 million means roughly half a year of reduced life expectancy per person on average. As the Baltic Sea and the North Sea ship emissions are representative of 2009 rather than 2010, the 2010 YOLL is labelled as 2009 in the table.

These numbers can be compared to previous calculations of the effects of present ship emissions by Hammingh et al. (2012) and Brandt et al. (2013). The calculations in Hammingh et al. (2012) have also been made with the EMEP model, but with a $50 \times 50 \mathrm{~km}^{2}$ horizontal resolution and a different methodology for calculating YOLL from $\mathrm{PM}_{2.5}$. Compared to the YOLLs listed here their numbers are lower for most countries listed (as the YOLL calculations applies the population above the age of 30 , and assuming a life expectancy of 80 years, the numbers in Table 2 have been divided by 50 to get comparable annual figures). The contributions to YOLL from international shipping in the North Sea and the Baltic Sea listed in Brandt et al. (2013) are difficult to compare, as they represent different regions from those listed in Table 2. Their calculated annual YOLL in Europe from international shipping in 2011 is about a factor of 3 higher than the similar contribution to the countries listed in Table 2. However, their figures include the effects on YOLL also from ozone, and on Europe as a whole.

Modelled concentrations of daily maximum ozone (Fig. 2c) in 2010 generally increase from north to south. In the high $\mathrm{NO}_{\mathrm{x}}$ emitting areas around the North Sea ozone levels are particularly low as a result of $\mathrm{NO}_{\mathrm{x}}$ titration. Figure $3 \mathrm{~b}$ shows the annually accumulated SOMO35 - SOMO35 is an indicator for health impacts for ozone recommended by $\mathrm{WHO}$ and is defined as the yearly sum of the daily maximum of $8 \mathrm{~h}$ running average ozone over $35 \mathrm{ppb}$. As for ozone, high 


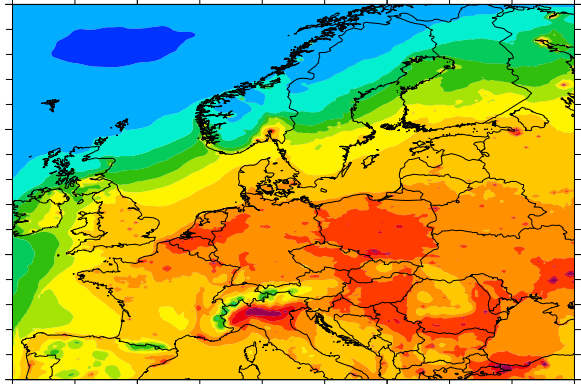

a) $\mathrm{PM}_{10}$ in $\mu \mathrm{g} \mathrm{m}^{-3}$

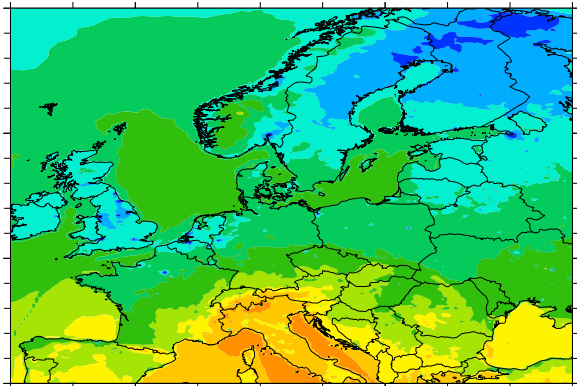

c) Daily max. ozone in $\mathrm{ppb}_{v}$

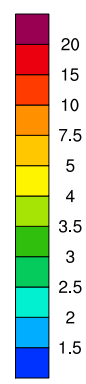

ir $3=$

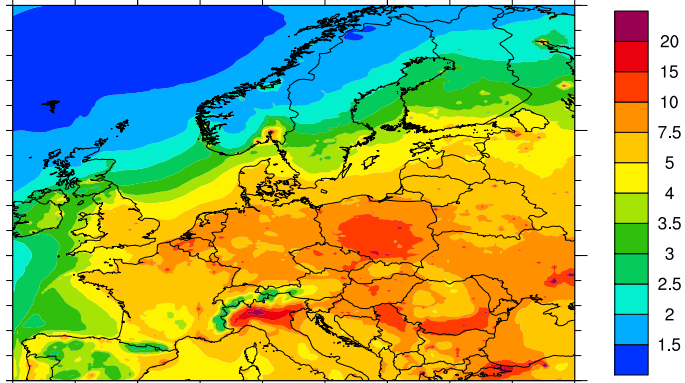

b) $\mathrm{PM}_{2.5}$ in $\mu \mathrm{g} \mathrm{m}^{-3}$

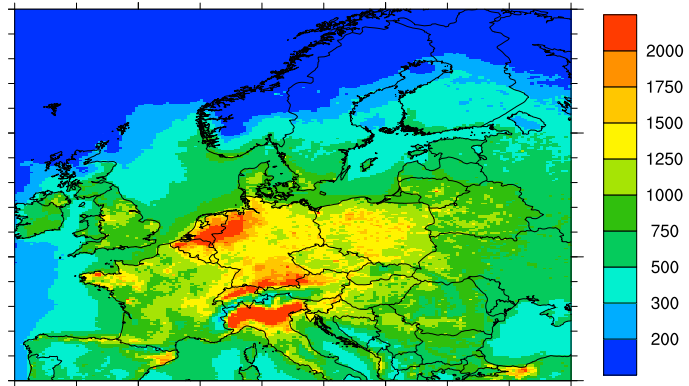

d) Total Dep. of $\mathrm{N}$ in $\mathrm{mg} \mathrm{m}^{-2}$

Figure 2. Modelled annual-mean concentrations of $\mathrm{PM}_{10}$ (a), $\mathrm{PM}_{2.5}$ (b), daily maximum ozone (c), and the total deposition of nitrogen (d).

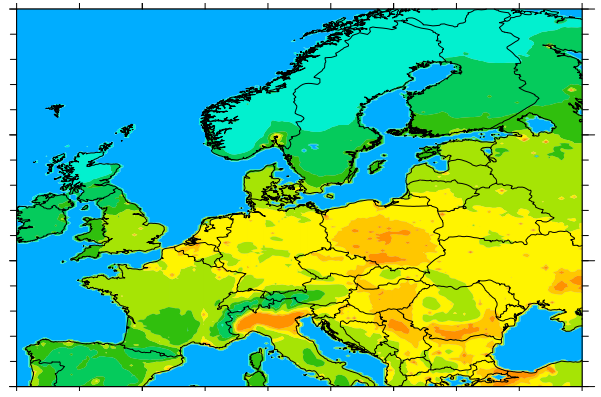

a) 2010 (2009 Ships) YOLL
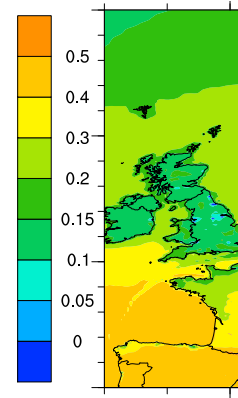

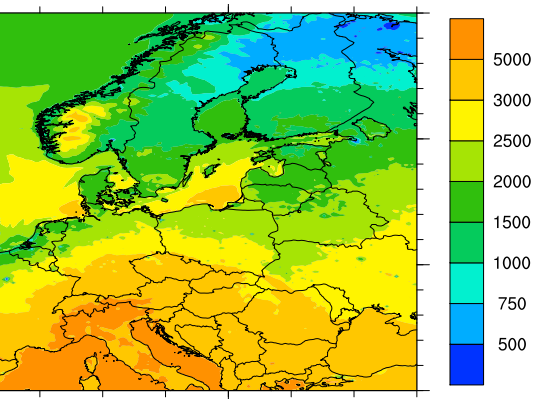

b) $\mathrm{SOMO} 35$ in $\mathrm{ppb}$ days

Figure 3. Years of life lost (YOLLs) per person (a) and SOMO35 (b) as calculated from the reference model calculation.

SOMO35 levels are in particular calculated in and around the Mediterranean countries. SOMO35 levels are relatively low around the Baltic Sea and the North Sea.

Figure $2 \mathrm{~d}$ shows the calculated deposition of total nitrogen. Large depositions of nitrogen are calculated for the North Sea region where there are both major landbased sources and ship emissions. The atmospheric deposition of nitrogen to the North Sea has remained static at about $300 \mathrm{Gg} \mathrm{yr}^{-1}$. The relative portions of nitrogen input for riverine, atmospheric and direct inputs are about $10: 3: 1$ (OSPAR Commission, 2000). For the Baltic Sea the atmospheric deposition of nitrogen contributes about one quarter to the total nitrogen load. It originates from emissions both inside and outside the Baltic catchment area, with shipping being the most important, and continuously increasing, source (Pawlak et al., 2009). The total depositions of oxidized nitrogen and sulfur calculated with 2010 land-based emissions are listed for the Baltic Sea and the North Sea and for a selection of countries close to these sea areas in Tables 3 and 4. The tabulated depositions for 2010 have been calculated with the ship emissions for 2009 as listed in Table 1 .

\subsection{Effects of North Sea and Baltic Sea 2009 ship emissions}

In addition to the reference model run, model perturbation runs have been made excluding all ship emissions from the Baltic Sea and the North Sea. Figure 4 shows the contributions from Baltic Sea and North Sea ship emissions to $\mathrm{PM}_{2.5}$ concentrations and depositions of nitrogen in the region. The contributions are shown in percent and as concentrations of 
Table 2. The first row gives the total number of years of life lost (YOLLs) summed up per country calculated with 2010 emissions (ship emissions in the Baltic Sea and the North Sea for 2009). Also listed are the percentage reductions from 2010 to 2030 under current regulation (second row), and the share from shipping calculated with ship emissions for 2009 and 2011 relative to the 2010 land based emissions (under "From Ships"). The percentage contribution from shipping in 2030 is listed both with and without a NECA implemented in the two sea areas (last two rows). Reductions in YOLLs from shipping are mainly caused by stricter controls of ship emissions of $\mathrm{SO}_{\mathrm{x}}$.

\begin{tabular}{|c|c|c|c|c|c|c|c|c|c|c|c|c|}
\hline Country $^{\mathrm{a}}$ & $\mathrm{BE}$ & NL & $\mathrm{DE}$ & GB & DK & NO & SE & FI & PL & LV & LT & $\mathrm{EE}$ \\
\hline YOLL $^{\mathrm{b}}$ in 2010 & 4061 & 4665 & 26071 & 11716 & 660 & 657 & 928 & 629 & 18085 & 562 & 986 & 169 \\
\hline Change, 2010 to 2030 & $-26 \%$ & $-31 \%$ & $-31 \%$ & $-31 \%$ & $-32 \%$ & $-12 \%$ & $-22 \%$ & $-16 \%$ & $-28 \%$ & $-22 \%$ & $-20 \%$ & $-17 \%$ \\
\hline $\begin{array}{l}\text { From Ships } \\
\text { in } 2009\end{array}$ & $6.5 \%$ & $9.7 \%$ & $3.8 \%$ & $6.3 \%$ & $11.7 \%$ & $6.5 \%$ & $10.0 \%$ & $4.9 \%$ & $1.6 \%$ & $3.1 \%$ & $2.9 \%$ & $5.0 \%$ \\
\hline in 2011 & $6.2 \%$ & $8.7 \%$ & $3.8 \%$ & $5.5 \%$ & $9.5 \%$ & $4.1 \%$ & $8.0 \%$ & $4.2 \%$ & $1.4 \%$ & $2.7 \%$ & $2.7 \%$ & $4.4 \%$ \\
\hline In 2030 No NECA & $5.5 \%$ & $7.9 \%$ & $3.6 \%$ & $6.0 \%$ & $9.2 \%$ & $3.2 \%$ & $6.7 \%$ & $3.0 \%$ & $1.4 \%$ & $2.4 \%$ & $2.3 \%$ & $3.3 \%$ \\
\hline In 2030 with NECA & $4.4 \%$ & $6.5 \%$ & $2.7 \%$ & $4.8 \%$ & $7.5 \%$ & $2.8 \%$ & $5.5 \%$ & $2.5 \%$ & $1.1 \%$ & $1.9 \%$ & $1.7 \%$ & $2.7 \%$ \\
\hline
\end{tabular}

${ }^{a}$ BE: Belgium, NL Netherlands, DE: Germany, GB: Great Britain, DK: Denmark, NO: Norway, SE: Sweden, FI: Finland, PL: Poland, LV: Latvia, LT: Lithuania, EE: Estonia. $\mathrm{b}$ YOLLs in thousands.

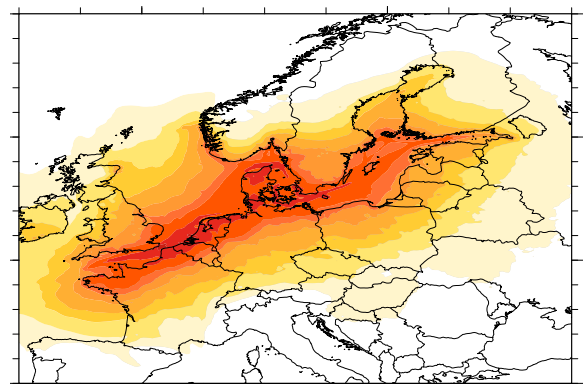

a) $\mathrm{PM}_{2.5}\left(\mu \mathrm{g} \mathrm{m}^{-3}\right)$ from shipping

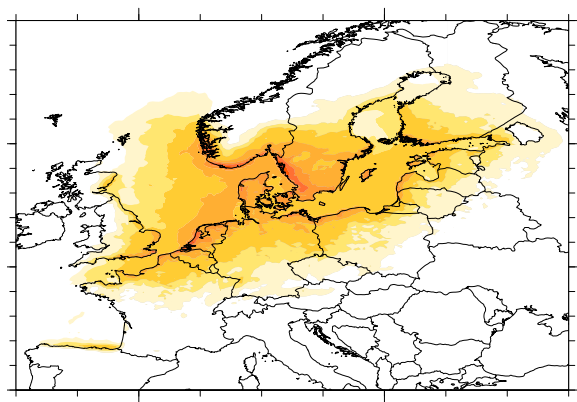

c) Total Dep. of $\mathrm{N}\left(\mathrm{mg} \mathrm{m}^{-2}\right)$ from shipping
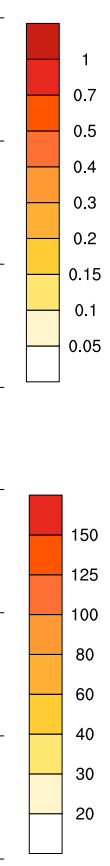

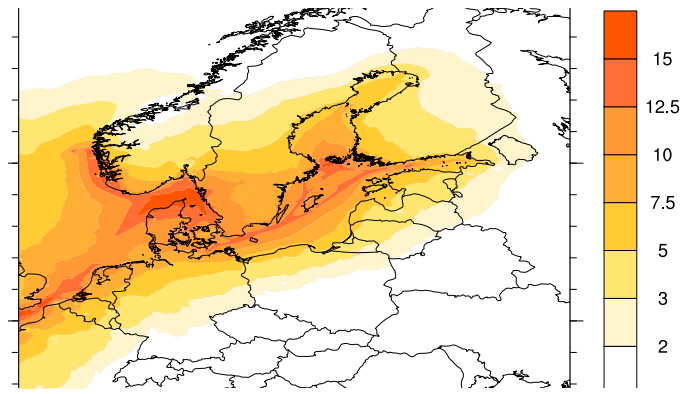

b) $\mathrm{PM}_{2.5}$ from shipping in percent

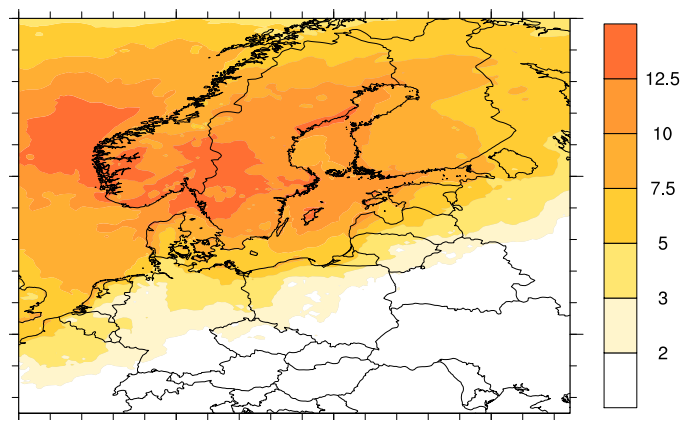

d) Total Dep. of $\mathrm{N}$ from shipping in percent

Figure 4. Contributions from year 2009 ship emissions in the Baltic Sea and the North Sea to $\mathrm{PM}_{2.5}$ concentrations (a) and in percent (b). Contributions to the total deposition of nitrogen in $\mathrm{mg} \mathrm{m}^{-2}$ (c) and in percent (d).

$\mathrm{PM}_{2.5}$ and deposited mass of nitrogen. The calculated effects on $\mathrm{PM}_{10}$ (not shown) are very similar to the effects on $\mathrm{PM}_{2.5}$ as most of the PM from shipping is SIAs (secondary inorganic aerosols), or has been emitted with a particle size below $2.5 \mu \mathrm{g} \mathrm{m}^{-3}$.

As shown in Fig. 4a and b, a significant part of the calculated $\mathrm{PM}_{2.5}$ in land areas close to the Baltic Sea and the North Sea can be attributed to shipping. As a result the calculated area with $\mathrm{PM}_{2.5}$ concentrations exceeding the maximum $\mathrm{PM}_{2.5}$ (see Fig. 2b) of $10 \mu \mathrm{g} \mathrm{m}^{-3}$ recommended by
WHO is substantially lower in Belgium, the Netherlands and Luxembourg when calculated without ship emissions in the two sea areas. Consequently, the calculated YOLL is also reduced when ship emissions are excluded (Fig. 5a and Table 2). Based on our model results, shipping was responsible for about $10 \%$ (range: $6-12 \%$ ) of calculated YOLL in the small- and medium-sized countries bordering the North Sea. In general, contributions to countries around the Baltic Sea are smaller than around the North Sea because ship emissions are lower here. Where the ship tracks are close to the 
Table 3. Depositions of oxidized nitrogen with units $100 \mathrm{Mg}$ as $\mathrm{N}$ calculated with 2010 land-based emissions and ship emissions in the Baltic Sea and the North Sea for 2009. The change in depositions between 2010 (2009 ship emissions) and 2030 is given in percent. The percentage contributions from ships in 2009 and 2011 are calculated relative to the 2010 land-based emissions. The share from shipping in 2030 is listed both with and without a NECA implemented in the two sea areas.

\begin{tabular}{|c|c|c|c|c|c|c|c|c|c|c|c|c|c|c|}
\hline Country $^{\mathrm{a}}$ & BAS & NOS & $\mathrm{BE}$ & NL & $\mathrm{DE}$ & GB & DK & $\mathrm{NO}$ & SE & FI & PL & LV & LT & $\mathrm{EE}$ \\
\hline Dep. N (100 Mg), 2010 & 1153 & 1919 & 168 & 194 & 2028 & 627 & 184 & 403 & 833 & 614 & 1604 & 237 & 261 & 156 \\
\hline Change, 2010 to 2030 & $-38 \%$ & $-43 \%$ & $-45 \%$ & $-43 \%$ & $-50 \%$ & $-47 \%$ & $-42 \%$ & $-37 \%$ & $-37 \%$ & $-33 \%$ & $-42 \%$ & $-31 \%$ & $-33 \%$ & $-29 \%$ \\
\hline \multicolumn{15}{|l|}{ From ships } \\
\hline in 2009 & $17 \%$ & $18 \%$ & $11 \%$ & $16 \%$ & $8 \%$ & $11 \%$ & $21 \%$ & $20 \%$ & $20 \%$ & $14 \%$ & $6 \%$ & $10 \%$ & $8 \%$ & $13 \%$ \\
\hline in 2011 & $17 \%$ & $17 \%$ & $12 \%$ & $16 \%$ & $8 \%$ & $11 \%$ & $20 \%$ & $17 \%$ & $19 \%$ & $15 \%$ & $6 \%$ & $11 \%$ & $8 \%$ & $14 \%$ \\
\hline in 2030 no NECA & $25 \%$ & $29 \%$ & $22 \%$ & $29 \%$ & $15 \%$ & $21 \%$ & $35 \%$ & $29 \%$ & $29 \%$ & $19 \%$ & $10 \%$ & $13 \%$ & $11 \%$ & $17 \%$ \\
\hline 2030 with NECA & $19 \%$ & $24 \%$ & $17 \%$ & $24 \%$ & $11 \%$ & $16 \%$ & $28 \%$ & $23 \%$ & $23 \%$ & $14 \%$ & $7 \%$ & $10 \%$ & $8 \%$ & $12 \%$ \\
\hline
\end{tabular}

a BAS: Baltic Sea, NOS: North Sea, BE: Belgium, NL Netherlands, DE: Germany, GB: Great Britain, DK: Denmark, NO: Norway, SE: Sweden, FI: Finland, PL: Poland, LV: Latvia, LT: Lithuania, EE: Estonia.

Table 4. Depositions of sulfur with units $100 \mathrm{Mg}$ of $\mathrm{S}$ calculated with 2010 land-based emissions and ship emissions in the Baltic Sea and the North Sea for 2009. The change in depositions between 2010 (2009 ship emissions) and 2030 is given in percent. The percentage contributions from ships in 2009 and 2011 are calculated with 2010 land-based emissions. Also listed are the percentage contributions from ship emissions in the two sea areas in 2030.

\begin{tabular}{|c|c|c|c|c|c|c|c|c|c|c|c|c|c|c|}
\hline Country $^{a}$ & BAS & NOS & $\mathrm{BE}$ & NL & $\mathrm{DE}$ & GB & DK & NO & SE & FI & PL & $\mathrm{LV}$ & LT & $\mathrm{EE}$ \\
\hline Dep. S (100 Mg), 2010 & 1314 & 2189 & 192 & 198 & 1725 & 766 & 143 & 394 & 653 & 540 & 2393 & 222 & 263 & 143 \\
\hline Change, 2010 to 2030 & $-44 \%$ & $-53 \%$ & $-29 \%$ & $-37 \%$ & $35 \%$ & $-48 \%$ & $-47 \%$ & $-25 \%$ & $-33 \%$ & $-27 \%$ & $-41 \%$ & $-35 \%$ & $-36 \%$ & $-33 \%$ \\
\hline $\begin{array}{l}\text { From ships } \\
\text { in } 2009\end{array}$ & $21 \%$ & $26 \%$ & $8 \%$ & $17 \%$ & $5 \%$ & $7 \%$ & $25 \%$ & $12 \%$ & $15 \%$ & $8 \%$ & $1 \%$ & $4 \%$ & $3 \%$ & $8 \%$ \\
\hline in 2011 & $17 \%$ & $20 \%$ & $7 \%$ & $14 \%$ & $5 \%$ & $5 \%$ & $18 \%$ & $7 \%$ & $10 \%$ & $6 \%$ & $1 \%$ & $3 \%$ & $2 \%$ & $6 \%$ \\
\hline in 2030 & $3.4 \%$ & $4.7 \%$ & $0.9 \%$ & $2.3 \%$ & $0.7 \%$ & $1.2 \%$ & $4.2 \%$ & $1.5 \%$ & $2.1 \%$ & $1.0 \%$ & $0.2 \%$ & $0.7 \%$ & $0.5 \%$ & $1.1 \%$ \\
\hline
\end{tabular}

shore there are, however, marked contributions also around the Baltic Sea. It should also be noted that the effects of elevated emissions in ports are poorly resolved in the dispersion calculations, and the effects there are likely to be higher than shown in this study.

The effects of total depositions of nitrogen (wet and dry) from ship emissions are shown both as contributions in $\mathrm{mg}(\mathrm{N}) \mathrm{m}^{-2}$ (Fig. 4c), and as a percentage of total depositions (Fig. 4d). Depositions of nitrogen from ships are high in and around the sea areas, often peaking along the shorelines as a result of high precipitation rates here. The percentage contributions differ from the contributions in $\mathrm{mg}(\mathrm{N}) \mathrm{m}^{-2}$ because relatively high contributions, around $10 \%$ or more, are seen over widespread areas in the Nordic countries and the Eastern Atlantic as a larger fraction of the nitrogen depositions here originates from long-range transport rather than local emissions. The calculated contributions to depositions of oxidized nitrogen and oxidized sulfur from ship emissions in the Baltic Sea and the North Seas to the two sea areas, and to selected countries close to these sea areas, are listed in Tables 3 and 4. The contribution is significant for all the countries listed in the tables, and in particular for countries where a large portion of the landmasses are close to the sea as is the case for Denmark, the Netherlands and Belgium. Larger countries, as Poland and Germany, are more affected by land-based emissions as a large portion of the area lies far from the shore. Note that, whereas the percentage depositions of nitrogen in Fig. 4d include also reduced nitrogen, the numbers in Table 3 include oxidized nitrogen only, hence the larger relative contributions from shipping in the table.

Figure $5 \mathrm{~b}$ shows the effects of emissions from the Baltic Sea and North Sea shipping on SOMO35. In general, emissions from shipping result in a slight increase in calculated SOMO35, but in and around the major shipping tracks calculated SOMO35 is reduced as a result of $\mathrm{NO}_{\mathrm{x}}$ titration following the $\mathrm{NO}_{\mathrm{x}}$ increase due to ships. This is also demonstrated in the calculated country-averaged SOMO35 levels in Table 5. The calculated effects of ship emissions in the Baltic Sea and the North Sea are decreased SOMO35 (negative percentage change) in Belgium and the Netherlands, and an increase for all other countries listed.

\subsection{Calculated effects of changes in ship emissions from 2009 to 2011}

Since July 2010 the maximum allowed content of sulfur in fuels has been $1 \%$ in the Baltic Sea and the North Sea. In order to see the effects of emission changes, additional model calculations have been made with estimated ship emissions for 2011. As seen in Fig. 6a, calculated concentrations of sulfate are reduced. As a result of the reductions in sulfur emissions concentrations of SIA (Fig. 6b) and $\mathrm{PM}_{2.5}$ (Fig. 6c) 


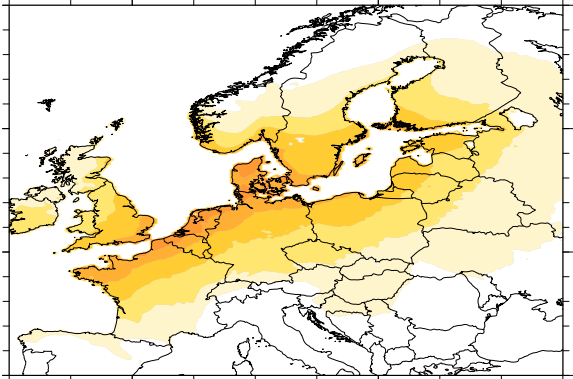

a) YOLL per person from shipping

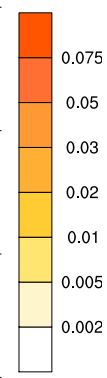

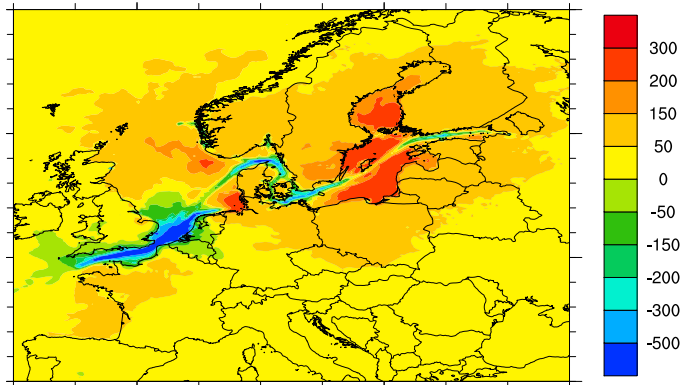

b) SOMO35 from shipping

Figure 5. YOLL per person (left) and SOMO35 (right) from year 2009 shipping in the Baltic Sea and the North Sea. Contributions from ship emissions are calculated as reference run minus the model run that excludes ship emissions.

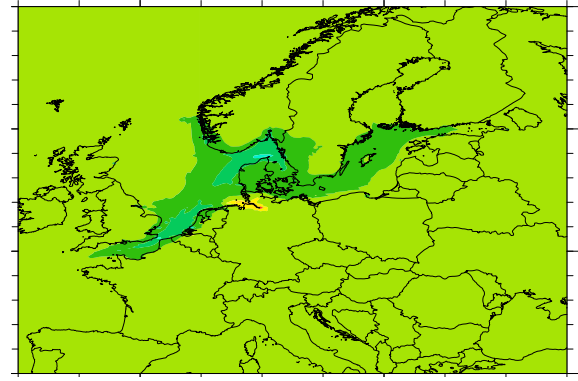

a) $\mathrm{SO}_{4}\left(\mu \mathrm{g} \mathrm{m}^{-3}\right) 2011-2009$

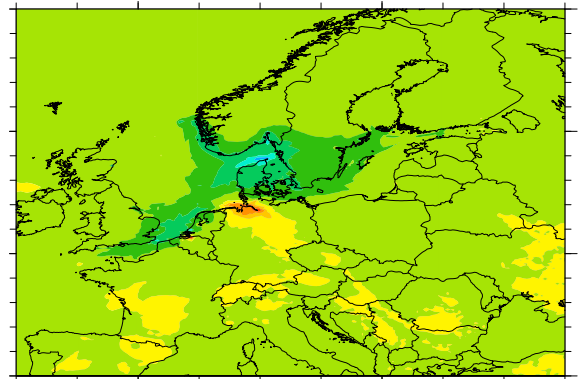

c) $\mathrm{PM}_{2.5}\left(\mu \mathrm{g} \mathrm{m}^{-3}\right) 2011-2009$
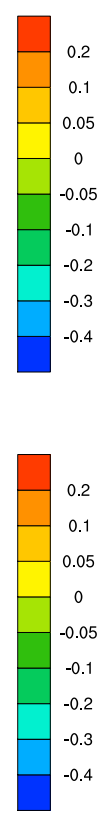

0.2
0.1
0.05
0
-0.05
-0.1
-0.2
-0.3
-0.4

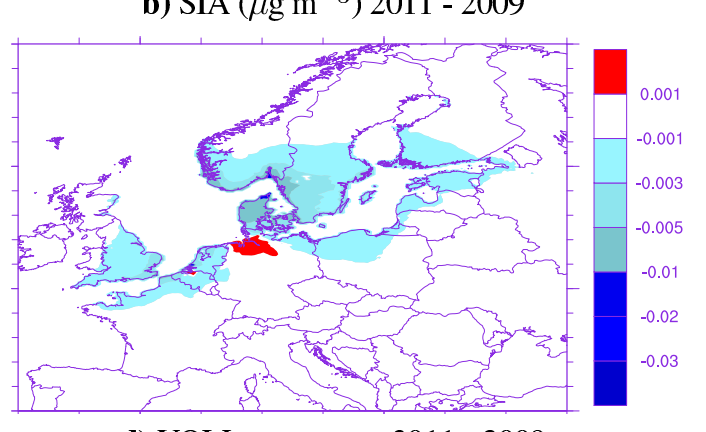

d) YOLL per person 2011 - 2009

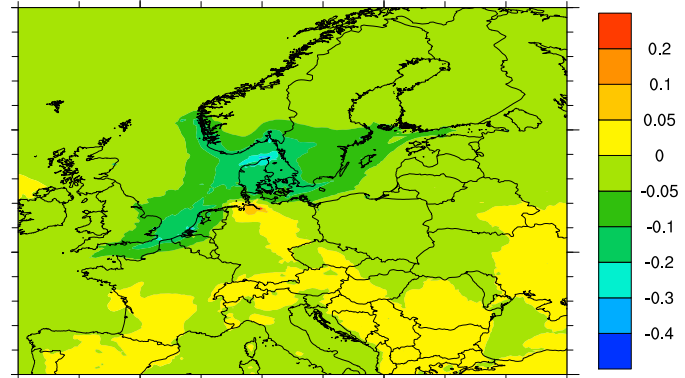

b) $\operatorname{SIA}\left(\mu \mathrm{g} \mathrm{m}^{-3}\right) 2011-2009$

d) YOLL per person $2011-2009$

$$
\text { , }
$$

Figure 6. Model calculated difference, 2011 vs. 2009 ship emissions.

in general decrease. There is however a local increase in and around German North Sea ports, reflecting an increase in particular in activity and emissions here as a result of a recovery from the recession in 2008/09. There is also a large reported increase in small vessel activity, but this should have limited effect on $\mathrm{SO}_{\mathrm{x}}$ since most small vessels use low sulfur fuel. Figure $6 \mathrm{~d}$ shows the resulting differences in calculated YOLL, reflecting the changes in $\mathrm{PM}_{2.5}$. The calculated contributions from shipping to YOLL accumulated for selected countries near the two sea areas are also listed in Table 2 . Following the implementation of the lower sulfur limits in the SECAs and in EU ports, the share of YOLL attributed to shipping has fallen in the surrounding countries (Table 2). On a country basis, the largest impacts of the sulfur reduc- 


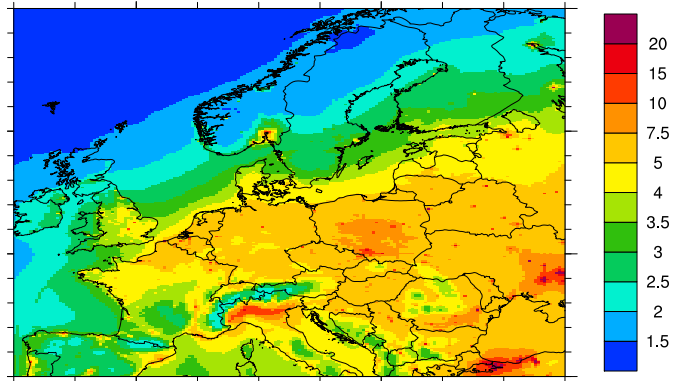

a) $\mathrm{PM}_{2.5}$ in $\mu \mathrm{g} \mathrm{m}^{-3}$

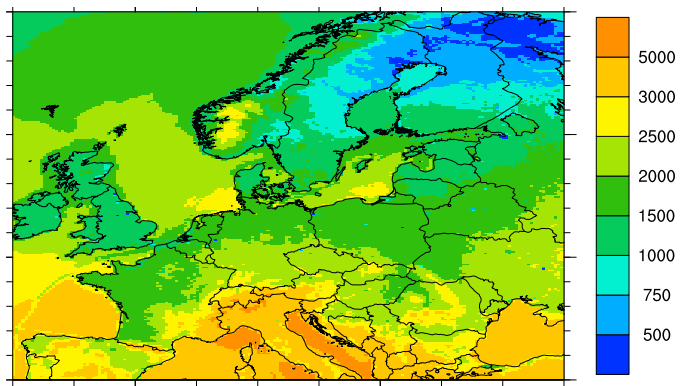

c) $\mathrm{SOMO} 23$ in 2030

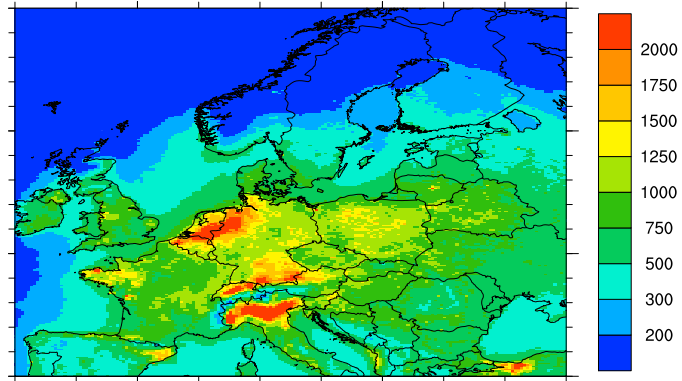

b) Total Dep. of $\mathrm{N}$ in $\mathrm{mg} \mathrm{m}^{-2}$

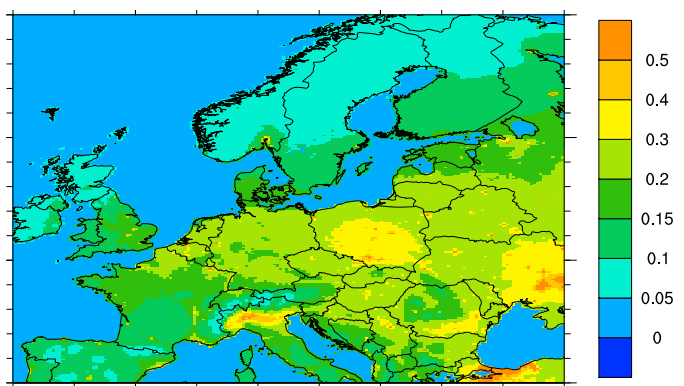

d) YOLLpp in 2030

Figure 7. Year 2030 model calculated annually averaged: (a) $\mathrm{PM}_{2.5}$ concentrations, (b) deposition of nitrogen, (c) SOMO35 and (d) YOLLpp.

Table 5. SOMO35 per country calculated with 2010 emissions (ship emissions in the Baltic Sea and the North Sea for 2009). Also listed are the percentage reductions from 2010 to 2030 under current regulation (second row), and the percentage share from shipping calculated with ship emissions for 2009 relative to the 2010 land-based emissions. The percentage contribution from shipping in 2030 is listed both with and without a NECA implemented in the two sea areas (last two rows). Negative percentage contributions mean an increase in calculated concentrations.

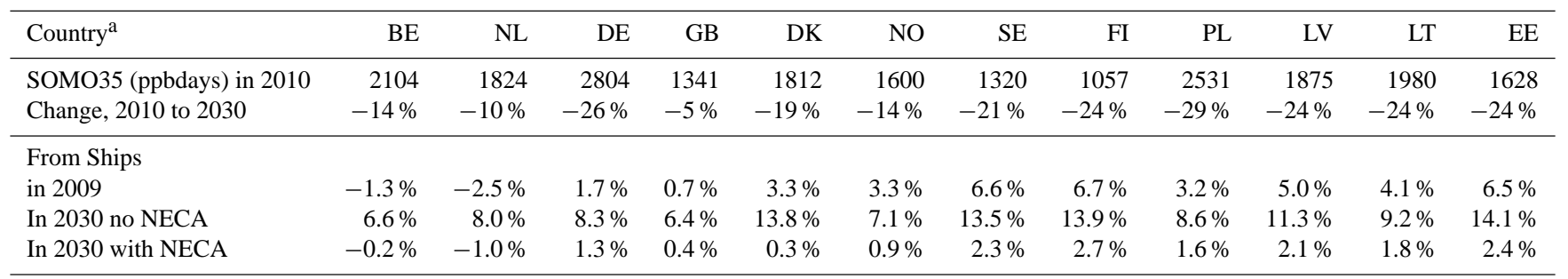

a BE: Belgium, NL Netherlands, DE: Germany, GB: Great Britain, DK: Denmark, NO: Norway, SE: Sweden, FI: Finland, PL: Poland, LV: Latvia, LT: Lithuania, EE: Estonia.

changes in depositions in Table 3 partly reflect regional changes in emissions.

\subsection{Calculated effects of Baltic Sea and North Sea ship emissions in 2030}

As explained in Sect. 2.1.1 emissions from shipping in the Baltic Sea and the North Sea will change, with substantial emission reductions in particular for sulfur, and partially also for particles. Emissions of $\mathrm{NO}_{\mathrm{x}}$ may remain at approximately the same levels, but if the two sea areas are accepted as NECAs, $\mathrm{NO}_{\mathrm{x}}$ emissions will be markedly reduced. Emissions of $\mathrm{CO}$ are expected to increase slightly. Modelled concentrations of $\mathrm{PM}_{2.5}$, depositions of nitrogen, SOMO35 and
YOLL for 2030 are shown in Fig. 7, and should be compared to the levels calculated for 2010 (Fig. 2). The calculations of YOLL have been made with the same population density distributions as in the calculations for 2010, and do not take into account changes in population density and the projected ageing of the European population. Using the same population density has the advantage that the calculations for 2030 and 2010 are directly comparable in terms of emission changes. YOLL and depositions of oxidized sulfur and oxidized nitrogen as well as SOMO35 calculated for year 2030 are also shown for selected countries in Tables 2, 3, 4 and 5 respectively. The calculations show that the expected changes in land- and sea-based emissions in Europe from 2010 to 2030 


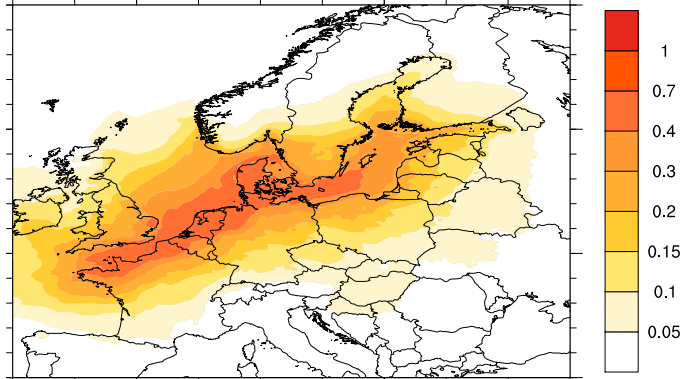

a) $\mathrm{PM}_{2.5}\left(\mu \mathrm{g} \mathrm{m}^{-3}\right)$ from shipping in 2030

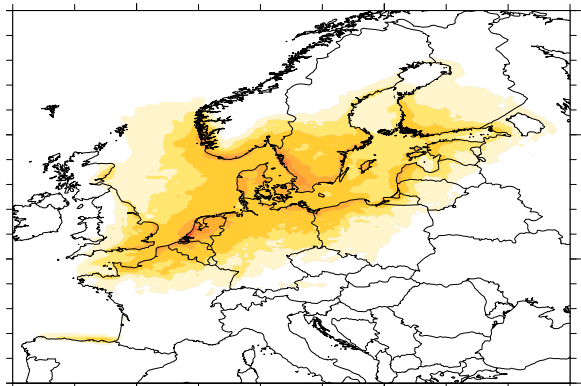

c) Dep. of $\mathrm{N}\left(\mathrm{mg} \mathrm{m}^{-2}\right)$ from shipping in 2030

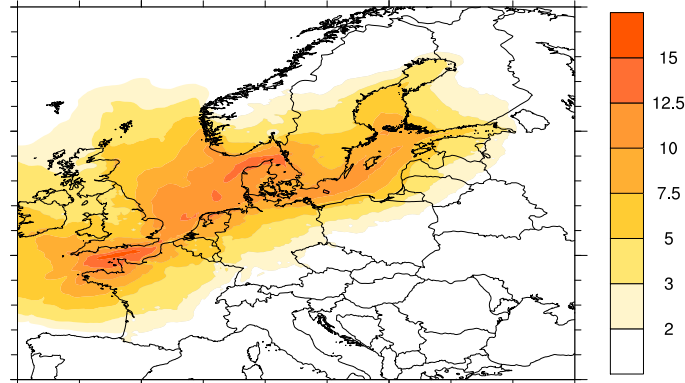

b) $\mathrm{PM}_{2.5}$ from shipping in 2030 in percent

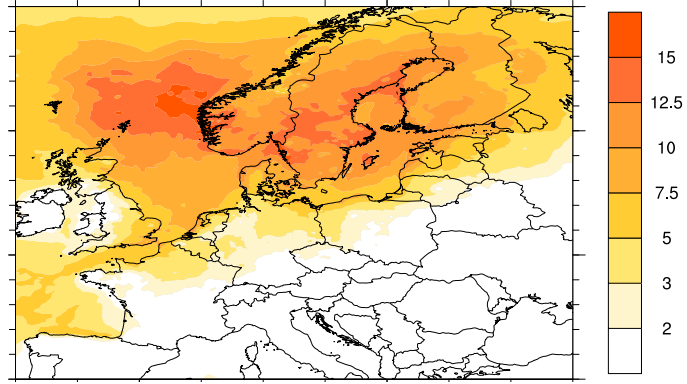

d) Dep. of $\mathrm{N}$ from shipping in 2030 in percent

Figure 8. Contributions from ship emissions in the Baltic Sea and the North Sea in year 2030 to $\mathrm{PM}_{2.5}$ concentrations (a) and in percent (b). Contributions to the total deposition of nitrogen in $\mathrm{mg} \mathrm{m}^{-2}$ (c) and in percent (d).

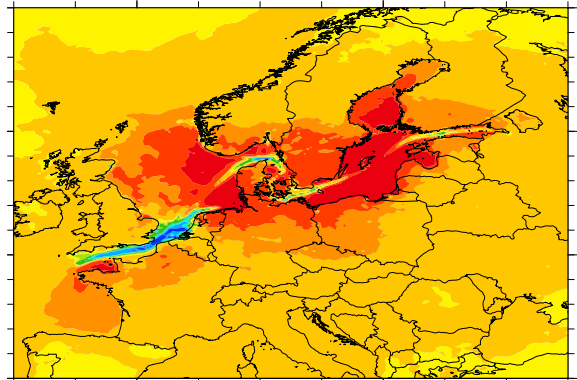

a) SOMO25 from shipping in 2030
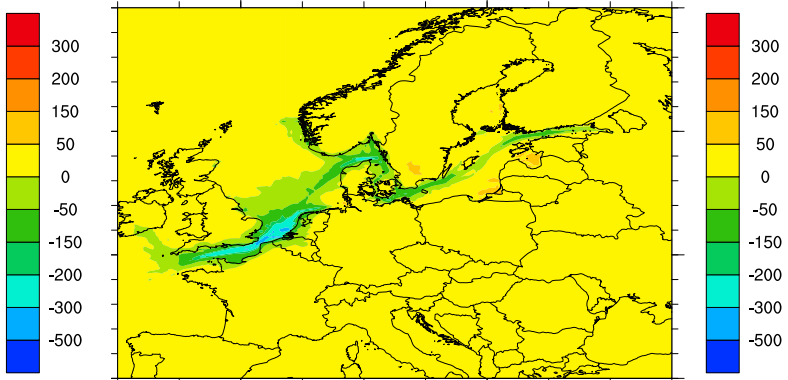

b) SOMO35 NoNECA - NECA in 2030

Figure 9. Year 2030 differences in SOMO35 in ppb days. Left, calculations as the 2030 model run without a NECA minus a model run excluding ship emissions in the Baltic Sea and the North Sea. Right, calculations as the 2030 model run without a NECA minus a model run with NECA included.

will have positive effects, with decreases in pollutant concentrations and depositions and subsequent environmental benefits and reductions in health indicators as SOMO35 and YOLL. Calculated depositions of nitrogen and sulfur are reduced by almost $40 \%$ between 2010 and 2030 for the countries listed in Tables 3 and 4. For the same set of countries YOLL is reduced by an average of about $25 \%$ (Table 2), but with a considerable spread, as there are also large natural contributions to $\mathrm{PM}_{2.5}$. Calculated reductions in SOMO35 from 2010 to 2030 listed in Table 5 range from just $5 \%$ in Great Britain to as much as $29 \%$ in Poland, downwind of major pollutant regions in Europe.
Figure 8 shows the effects of ship emissions from the Baltic Sea and the North Sea in 2030 on $\mathrm{PM}_{2.5}$ concentrations and nitrogen depositions. Compared to the contributions in 2009 (Fig. 4) the effects of ship emissions on $\mathrm{PM}_{2.5}$ levels are expected to decrease substantially because of the sulfur reduction requirements which have already been agreed by the IMO. Furthermore, depositions of sulfur to the sea areas and to the neighbouring countries will become very small (Table 4).

If the Baltic Sea and the North Sea are not accepted as NECAs, emissions of $\mathrm{NO}_{\mathrm{x}}$ from the Baltic Sea and the North Sea are likely to remain close to present levels. As a result, depositions of nitrogen in 2030, as shown in Fig. 8c, 
will be virtually unchanged from their present (2009) levels (Fig. 4c.) As the land-based $\mathrm{NO}_{\mathrm{x}}$ emissions are projected to decrease substantially over the same time span, the percentage contribution from ship emissions will increase, as can be seen by comparing Fig. 8d and Fig. 4d. This is also illustrated by comparing the shares from shipping in 2009 and 2030 in Table 3. Compared to 2010, the chemical regime in Europe, and the Baltic Sea and North Sea regions in particular, will be very different in 2030 as a result of substantial reductions in continental emissions. Even though $\mathrm{NO}_{\mathrm{x}}$ emissions from ships will remain virtually unchanged, the calculated effects on SOMO35 (Fig. 9a) is considerably larger than in 2009 (Fig. 5b). The ozone titration zone around the ship tracks is considerably smaller than in 2010. This is also shown in Table 5 where the calculated effects from ship emission on SOMO35 averaged over the countries are larger compared to 2009. Furthermore, contrary to 2009, ship emissions contribute to increased SOMO35 levels also in Belgium and the Netherlands.

If the two sea areas are accepted as NECAs from 2016, a substantial part of the fleet will be replaced by ships with TIER III technology by 2030 . As a result, marked reductions in $\mathrm{NO}_{\mathrm{x}}$ emissions will be achieved by 2030 (see Table 1). Postponing the requirements for Tier III to 2021 will delay the reductions in $\mathrm{NO}_{\mathrm{x}}$ emissions. Tables 2 and 3 list the contributions to accumulated YOLL and depositions of oxidized nitrogen for selected countries from shipping in the two sea areas assuming that the NECAs are implemented from year 2016. The resulting fractional reductions in nitrogen depositions and YOLL are roughly in the same range as the emission reductions. With the low sulfur and PM emissions from shipping after the implementation of the SECAs, nitrates, formed from $\mathrm{NO}_{\mathrm{x}}$, will be the dominant source of PM from shipping.

From 2010 to 2030 land-based emissions of air pollutants in Europe are expected to drop significantly. As a result only small reductions in the percentage contributions to detrimental health effects and to nitrogen depositions can be expected, even though the absolute contributions from international shipping are significantly reduced. This is in good agreement with the findings of Brandt et al. (2013).

As shown in Fig. 9b, calculated changes in SOMO35 in the two sea areas are relatively small if NECAs are implemented. This is also illustrated in Table 5. Around the Baltic sea, downwind of the shipping tracks, the country averaged increase from not implementing NECAs are 2-3\%. Contrary to the calculations with ship emissions excluded, titration effects in and around the North Sea again result in decreased SOMO35 levels in Belgium and the Netherlands.

\section{Conclusions}

As a result of recently implemented measures, emissions of sulfur from shipping in the Baltic Sea and the North Sea have been reduced. Our model calculations show that these emission reductions already have had positive effects on air pollution and deposition. From 2015 the sulfur fuel regulations will be further strengthened, and, provided the ships comply to the rules, significant further improvements in air quality as well as deposition of sulfur will result for land areas bordering the two sea areas. As the regulations are primarily linked to fuel use, these improvements will have immediate effects. So far there are no plans for additional European sea areas being defined as SECA in the foreseeable future.

Emissions from shipping also affect acidification. Emissions of acidifying components from all sources have been reduced significantly over the past decades. Even so, critical loads for acidification are exceeded in areas at risk around the Baltic Sea and the North Sea (Gauss et al., 2013). A large part of these areas are located relatively close to the sea. As shown in Table 4, planned - or already implemented - emission reductions of sulfur from shipping contribute to a lowering the depositions and thus less acidification. Implementing NECAs in the two sea areas will also contribute to less acidification.

The transition to TIER II on new ships, and new-built ships becoming more efficient, will help stabilize $\mathrm{NO}_{\mathrm{x}}$ emissions from shipping. Given a moderate increase in ship activity, $\mathrm{NO}_{\mathrm{x}}$ emissions in the Baltic Sea and the North Sea will be virtually unchanged from 2010 to 2030, if NECAs are not implemented. The main contribution to $\mathrm{PM}_{2.5}$ from shipping will then be from $\mathrm{NO}_{\mathrm{x}}$ emissions. If, however, the two sea areas are accepted as NECAs, $\mathrm{NO}_{\mathrm{x}}$ emissions in 2030 will be significantly lower, thereby resulting in further reductions in the burden on health from shipping.

Critical loads for eutrophication are exceeded throughout most of Europe, including most of the land areas around the Baltic and the North Sea (Gauss et al., 2013). As shown in Table 3 and Fig. 2d, a significant fraction of the calculated nitrogen depositions are from shipping. If NECAs are implemented this fraction will remain almost unchanged as land-based emissions are also expected to decrease. Without NECAs the fraction from shipping will increase.

The formation of secondary inorganic aerosols, and deposition of both sulfate and nitrate are likely to change under different chemical regimes. In a less acidic cloud environment the oxidation of $\mathrm{SO}_{2}$ to sulfate will be faster. Compared to $\mathrm{NO}_{\mathrm{x}}$, and in particular sulfur emissions, only moderate emission changes of ammonia are expected between 2010 and 2030. With a higher $\mathrm{NH}_{3} / \mathrm{NO}_{\mathrm{x}}$ ratio in the emissions more ammonia will be available for nitrate aerosol formation. A less acidic ground surface will result in more efficient deposition of nitrate and sulfate. These effects are included in the model calculations, but no sensitivity studies to assess their relative importance are included here. Including these effects has been shown to give marked improvements when comparing EMEP model calculations versus measured sulfate and nitrate concentrations and wet depositions (Schulz et al., 2013) 
Several factors will contribute to the uncertainty of the calculations of health effects presented here. In addition to the uncertainty in the EMEP model calculations, additional uncertainties are introduced with the calculations of health effects from the particle concentrations. For YOLL the uncertainty is partially reflected in the difference in the estimates presented in this study, and estimates presented by Hammingh et al. (2012) and Brandt et al. (2013). Uncertainties may stem from several factors, such as calculated $\mathrm{PM}_{2.5}$ concentrations, methodology in the YOLL calculations and resolution. (Population density is likely to be correlated to high pollution levels. As a result an increase in model resolution could result in an increase in calculated YOLL.)

In particular in and around the major shipping lanes, additional $\mathrm{NO}_{\mathrm{x}}$ emissions result in ozone titration, and a decrease in ozone expressed as SOMO35. In our calculations we show that this ozone titration zone will shrink as mainly land-based $\mathrm{NO}_{\mathrm{x}}$ emissions decrease. This is in good agreement with detailed model calculations with projected emission changes, demonstrating a future transition from NMVOC-limited to $\mathrm{NO}_{\mathrm{x}}$-limited regimes in large parts of Europe north of the Alps, except in the region in and around the English Channel, which will continue to be NMVOC-limited at least until 2020 (Beekmann et al., 2010). In NMVOC-limited regimes the production of ozone is controlled by the availability of NMVOC, while further enhancements of $\mathrm{NO}_{\mathrm{x}}$ there would lead to titration (and thus reduction) of ozone. In $\mathrm{NO}_{\mathrm{x}}-$ limited regimes, increases in $\mathrm{NO}_{\mathrm{x}}$ will cause increased formation of ozone.

In our model calculations the ship emissions are instantly diluted. Model calculations with a parameterization of the ship plumes suggest that with this approach we overestimate $\mathrm{NO}_{\mathrm{x}}$ concentrations and ozone formation (Huszar et al., 2010; Vinken et al., 2011). Our results may not be directly comparable as we use a much finer horizontal model resolution. In addition Vinken et al. (2011) find that the differences between the plume calculations and instant dilution are smallest over strongly polluted seas such as the North Sea. This suggests that implementing a parameterization of the ship plumes would not change our results significantly.

\subsection{Cost and effects: some final remarks}

The calculated effects on health and the environment from shipping are considerable. Our calculations show that the policy decisions to strengthen the emission regulations in EU ports and in the SECAs has had the intended effect of reducing pollution levels in and around the two sea areas. The implementation of even stricter regulations from 2015, and a possible future implementation of NECAs should result in further reductions in health effects and in adverse effects in the environment.

The results of this study indicate that significant health benefits can be achieved by restricting the exhaust emissions from marine engines. According to our results, the health im- pact from shipping in the North Sea and the Baltic Sea area can be reduced by roughly 1.5 million YOLLs with sulfur and nitrogen limits by 2030 . This estimate is not annualized, but represents the total contribution from the population above the age of 30 . As morbidity is not included in our estimates, the full health impacts of the emission reductions are not accounted for. Regardless, this study estimates that the annual health benefit ranges from 1.4 to 4.7 billion euros using the "value of life year" methodology as described in Hammingh et al. (2012). Including also morbidity, they found that YOLLs represent roughly $70 \%$ of the total health benefits. In addition to the health effect, there are significant benefits to the environment and to crops that are not monetized here.

The future price difference between residual and distillate fuels is difficult to predict. With current fuel prices (December 1st 2014) it is around 4 billion euros/year for the two sea areas. According to Johansson et al. (2013) estimated price difference for the annual costs of fuel switch will be between 2 and 6 billion euros. This is in the same cost range as the estimated savings from the improvements in health.

Currently it is unclear whether the tighter NECA regulations will be implemented in the Baltic Sea and the North Sea. LNG would be a viable option to meet the compliance costs of both $\mathrm{SO}_{\mathrm{x}}$ and $\mathrm{NO}_{\mathrm{x}}$ reduction at the same time. It is probable that LNG use will remain limited if NECA is not established in the study area. Ship owners may see it reasonable to withhold investments in new-builds and stick to low sulfur fuels with the current fleet until NECAs are declared. In the longer run, LNG and the requirements for energy efficiency improvements (IMO EEDI, Energy Efficiency Design Index) contribute to the ability to comply with EU Transport White Paper GHG reduction target of halving the maritime GHG emissions by 2050 . This is a very ambitious goal and it is unlikely to be reached without significant adoption of LNG and biofuels in ships.

However, biofuels are not expected to reach widespread use during the time described in the future scenarios of this study. There are currently some ship owners experimenting with marine biofuels (like MeriAura group in Finland), but it is unlikely that these will be adopted on a large scale if there are no financial incentives or legal obligations to support this shift. The emissions of $\mathrm{NO}_{\mathrm{x}}$ from Baltic Sea and North Sea shipping are gradually decreasing, but this will inevitably be a function of fleet renewal rate and traffic growth. Significant reduction of $\mathrm{NO}_{\mathrm{x}}$ will be reached when all pre-NECA constructed vessels are replaced with Tier III compliant ships. This will take roughly 30 years from the NECA introduction, which will occur around 2045 at the earliest if NECAs are established in 2016.

There are however several risk factors that can affect the foreseen improvements in the effects of ship emissions. The implementation of SECAs will most likely result in a substantial increase in the price of marine fuels (or alternatively, other approved technological methods with comparable re- 
ductions in sulfur emissions). The use of low sulfur distillate fuel $(0.1 \% \mathrm{~S})$ or the use of alternative fuels or scrubbers are expected to increase fuel costs by $30-80 \%$ compared to marine fuels with $1.5 \%$ sulfur content. The fuel cost increase depends strongly on the future price development of marine fuels and the $\mathrm{SO}_{\mathrm{x}}$ scrubber usage. With moderate $(50 \%)$ fuel price premium and wide adoption of scrubbers in all vessels with annual fuel consumption over 4000 tonnes in the SECAs, the fuel cost increase can be as low as $30 \%$. However, in the case of a high price premium (100\%) for the low sulfur fuel and no exhaust scrubber installations, the cost increase can be as high as $80 \%$ compared to the 2009 situation (1.5\% S) (Johansson et al., 2013; Notteboom et al., 2010). Johansson et al. (2013) note that further increases in the cost of shipping could result in a modal shift from ships to roads, potentially undermining the expected environmental and health-related benefits associated with reduced marine emissions. For several intra-Europe shipping routes the cost of shipping is already comparable to the cost of road transport. The large expected increase in the cost in marine fuels will make it tempting to use high sulfur fuels also in the SECAs. A system for compliance monitoring should therefore be put in place to ensure level competition and the obeyance of rules protecting human health and the environment.

Acknowledgements. This work has been partially funded by the EU Baltic Sea Region project BSR Innoship: project number 051, and EU FP7 TRANSPHORM: project number 243406.

Edited by: R. Harley

\section{References}

Amann, M., Heyes, C., Schöpp, W., and Mechler, R.: Modelling of Health Impacts of Fine Particles, in the rains review 2004, IIASA, available at: www.iiasa.ac.at/rains/review/ review-healthpm.pdf (last access: 11 August 2014), 2004.

Amann, M., Borken, J., Böttcher, H., Cofala, J., Hettelingh, J., Heyes, C., Holland, M., Hunt, A., Klimont, Z., Mantzos, L., 1. Ntziachristos, Obersteiner, M., Posch, M., Schneider, U., Schöpp, W., Slootweg, J., Witzke, P., Wagner, A., and Winiwarter, W.: Greenhouse gases and air pollutants in the European Union: baseline projections up to 2030, Ec4macs interim assessment, IIASA, available at: http://webarchive.iiasa.ac.at/rains/ reports/EC4MACS_IR_11.pdf (last access: 11 August 2014), 2011.

Andersson, C., Bergström, R., and Johansson, C.: Population exposure and mortality due to regional background PM in Europe Long term simulations of source region and and shipping contributions, Atmos. Environ., 43, 3614-3620, 2009.

Angelbratt, J., Mellqvist, J., Simpson, D., Jonson, J. E., Blumenstock, T., Borsdorff, T., Duchatelet, P., Forster, F., Hase, F., Mahieu, E., De Mazière, M., Notholt, J., Petersen, A. K., Raffalski, U., Servais, C., Sussmann, R., Warneke, T., and
Vigouroux, C.: Carbon monoxide $(\mathrm{CO})$ and ethane $\left(\mathrm{C}_{2} \mathrm{H}_{6}\right)$ trends from ground-based solar FTIR measurements at six European stations, comparison and sensitivity analysis with the EMEP model, Atmos. Chem. Phys., 11, 9253-9269, doi:10.5194/acp11-9253-2011, 2011.

Beekmann, M., and Vautard, R.: A modelling study of photochemical regimes over Europe:robustness and variability, Atmos. Chem. Phys., 10, 10067-10084, doi:10.5194/acp-10-100672010, 2010.

Brandt, J., Silver, J. D., Christensen, J. H., Andersen, M. S., Bønløkke, J. H., Sigsgaard, T., Geels, C., Gross, A., Hansen, A. B., Hansen, K. M., Hedegaard, G. B., Kaas, E., and Frohn, L. M.: Assessment of past, present and future health-cost externalties of air pollution in Europe and the contribution from international ship traffic using the EVA model system, Atmos. Chem. Phys., 13, 7747-7764, doi:10.5194/acp-13-7747-2013, 2013.

Chevron: Everything You Need to know About Marine Fuel, available at: http://www.chevronmarineproducts.com/docs/ everythingaboutfuels_v0108_lo.pdf (last access: 29 October 2014), 2012.

Colette, A., Granier, C., Hodnebrog, Ø., Jakobs, H., Maurizi, A., Nyiri, A., Bessagnet, B., D’Angiola, A., D'Isidoro, M., Gauss, M., Meleux, F., Memmesheimer, M., Mieville, A., Rouïl, L., Russo, F., Solberg, S., Stordal, F., and Tampieri, F.: Air quality trends in Europe over the past decade: a first multimodel assessment, Atmos. Chem. Phys., 11, 11657-11678, doi:10.5194/acp-11-11657-2011, 2011.

Colette, A., Granier, C., Hodnebrog, Ø., Jakobs, H., Maurizi, A., Nyiri, A., Rao, S., Amann, M., Bessagnet, B., D’Angiola, A., Gauss, M., Heyes, C., Klimont, Z., Meleux, F., Memmesheimer, M., Mieville, A., Rouïl, L., Russo, F., Schucht, S., Simpson, D., Stordal, F., Tampieri, F., and Vrac, M.: Future air quality in Europe: a multi-model assessment of projected exposure to ozone, Atmos. Chem. Phys., 12, 1061310630, doi:10.5194/acp-12-10613-2012, 2012.

Corbett, J., Winebrake, J., Green, E., Kasibhatla, P., and Eyring A. laurer, V.: Mortality from ship emissions: a global assessment, Environ. Sci. Technol., 41, 8512-8518, doi:10.1021/es071686z, 2007.

Corbett, J. J., Fischbeck, P. S., and Pandis, S. N.: Global nitrogen and sulfur inventories for oceangoing ships, J. Geophys. Res., 104, 3457-3470, 1999.

Endresen, Ø., Sørgård, E., Sundet, J., Dalsøren, S., Isaksen, I., Berglen, T., and Gravir, G.: Emission from international sea transport and environmental impact, J. Geophys. Res., 108, 4560, doi:10.1029/2002JD002898, 2003.

Eyring, V., Isaksen, I., Berntsen, T., Collins, W., Corbett, J., Endresen, Ø., Grainger, R., Moldanova, J., Schlager, H., and Stevenson, D.: Transport impacts on atmosphere and climate: shippingt, Atmos. Environ., 44, 4735-4771, 2007.

Fagerli, H., Nyíri, A., Jonson, J.E., Gauss, M., Benedictow, A., Steensen, B:M., Hjellbrekke, A.-G., Mareckova, K., Nyíri, A., and Wankmüller, R.: Status of transboundary pollution in 2010, in: Transboundary Acidification, Eutrophication and Ground Level Ozone in Europe in 2010, EMEP/MSC-W Status Report $1 / 2012$, The Norwegian Meteorological Institute, Oslo, Norway, 17-40, 2012.

Fuglestvedt, J., Shine, K., Berntsen, T., Cook, J., Lee, D., stenke, A., Skeie, R., Velders, G., and Waitz, I.: transport impacts on at- 
mosphere and climate: metrics, Atmos. Environ., 44, 648-677, 2010.

Gauss, M., Benedictow, A., Hjellbrekke, A.-G., Mareckova, K., Nyíri, A., and Wankmüller, R.: Status of transboundary pollution in 2011, in: Transboundary Acidification, Eutrophication and Ground Level Ozone in Europe in 2011, EMEP/MSC-W Status Report 1/2013, The Norwegian Meteorological Institute, Oslo, Norway, 17-42, 2013.

Hammingh, P., Holland, M., Geilenkirchen, G., Jonson, J., and Maas, R.: Assessment of the Environmental Impacts and Health Benefits of a Nitrogen Emission Control Area in the North Sea, PBL Netherlands Environmental Assessment Agency, the Hague/Bilthoven, 2012.

Huszar, P., Cariolle, D., Paoli, R., Halenka, T., Belda, M., Schlager, H., Miksovsky, J. and Pisoft, P.: Modeling the regional impact of ship emissions on $\mathrm{NO}_{x}$ and ozone levels over the Eastern Atlantic and Western Europe using ship plume parameterization, Atmos. Chem. Phys., 10, 6645-6660, doi:10.5194/acp-106645-2010, 2010.

IHS Fairplay: Lombard House, 3 Princess Way, Redhill, Surrey, RH1 1UP UK, 2012.

IMO: Prevention of air pollution from ships, Information on $\mathrm{NO}_{\mathrm{x}}$ Emissions from Shipping in the Baltic Sea Area, Mepc 57/inf.14, IMO (International Maritime Organization), available at: http:// docs.imo.org (last access: 11 August 2014), 2007.

IMO: Report of the Marine Environment Protection Committee on the Sixty-First Session, Mepc 61/24, IMO (International Maritime Organization), available at: http://docs.imo.org (last access: 11 August 2014), 2010.

Jalkanen, J.-P., Brink, A., Kalli, J., Pettersson, H., Kukkonen, J., and Stipa, T.: A modelling system for the exhaust emissions of marine traffic and its application in the Baltic Sea area, Atmos. Chem. Phys., 9, 9209-9223, doi:10.5194/acp-9-9209-2009, 2009.

Jalkanen, J.-P., Johansson, L., Kukkonen, J., Brink, A., Kalli, J., and Stipa, T.: Extension of an assessment model of ship traffic exhaust emissions for particulate matter and carbon monoxide, Atmos. Chem. Phys., 12, 2641-2659, doi:10.5194/acp-12-26412012, 2012.

Johansson, L., Jalkanen, J.-P., Kalli, J., and Kukkonen, J.: The evolution of shipping emissions and the costs of regulation changes in the northern EU area, Atmos. Chem. Phys., 13, 11375-11389, doi:10.5194/acp-13-11375-2013, 2013.

Jonson, J., Tarrasón, L., Klein, H., Vestreng, V., Cofala, J., and Whall, C.: Effects of ship emissions on European ground level ozone in 2020, Int. J. Remote Sens., 30, 4099-4110, 2009.

Jonson, J. E., Stohl, A., Fiore, A. M., Hess, P., Szopa, S., Wild, O., Zeng, G., Dentener, F. J., Lupu, A., Schultz, M. G., Duncan, B. N., Sudo, K., Wind, P., Schulz, M., Marmer, E., Cuvelier, C., Keating, T., Zuber, A., Valdebenito, A., Dorokhov, V., De Backer, H., Davies, J., Chen, G. H., Johnson, B., Tarasick, D. W., Stübi, R., Newchurch, M.J., von der Gathen, P., Steinbrecht, W., and Claude, H.: A multi-model analysis of vertical ozone profiles, Atmos. Chem. Phys., 10, 5759-5783, doi:10.5194/acp-10-5759-2010, 2010.

Jonson, J. E., Tarrasón, L., and Bartnicki, J.: Effects of International Shipping on European Pollution Levels, EMEP/MSC-W note 5/00, The Norwegian Meteorological Institute, Oslo, Norway, 2000.
Kalli, J., Jalkanen, J.-P., Johansson, L., and Repka, S.: Atmospheric emissions of European SECA shipping: long-term projections, WMU J. Marit. Affairs, 12, 129-145, doi:10.1007/s13437-0130050-9, 2013.

Maier, F., Bregon, A. O., Bissolli, P., Kennedy, J. J., Parker, D.E., Trigo, R. M., Barriopedro, D, Gouveia, C. M., Sensoy, S., and Achberger, C.: [Regional climates] Europe, in: State of the climate in 2010, Bull. Amer. Meteor. Soc., 92, 199-208, 2011.

Moldová, J., Fridell, E., Winnes, H., Holmin Fridell, S., Boman, J., Jedynska, A., Tishkova, V., Demirdjian, B., Joulie, S., Bladt, H., Ivleva, N.P., and Niessner, S.: Physical and chemical characterisation of PM emissions from two ships operating in European Emission Control Areas, Atmos. Meas. Tech., 6, 3577-3596, doi:10.5194/amt-6-3577-2013, 2013.

Notteboom, T., Delhaye, E., and Vanherle, K.: Analysis of the consequences of low sulphur fuel requirements, ITMMA - Universiteit Antwerpen, Belgium, available at: http://www.tmleuven.be/project/externekostmaritiem/ 2010FINALREPORT_LowSulphurRequirements.pdf (last access: 11 August 2014), 2010.

OSPAR Commission: Quality Status Report 2000 for the NorthEast Atlantic, Tech. rep., OSPAR Commission for the Protection of the Marine Environment of the North-East Atlantic, available at: http://www.ospar.org/content/content.asp? menu=00650830000000_000000_000000,2000.

Pawlak, J., Laamanen, M., and Andersen, J.: Eutrophication in the Baltic Sea, An Integrated Thematic Assessment of the Effects of Nutrient Enrichment in the Baltic Sea Region, Baltic Sea Environment Proceedings No. 115A, Helsinki Commisission, available at: http://helcom.fi/Lists/Publications/BSEP115Al

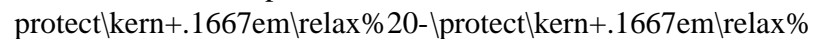
20Executivelprotectlkern+.1667em\relax\%20summary.pdf (last access: 11 August 2014), 2009.

Sculz, M., Benedictow, A., Schneider, P., Bartnicki, J., Valdebenito, A., Gauss, M. and Griesfeller, J.: Observed and modelled trends in EMEP region, in: Transboundary Acidification, Eutrophication and Ground Level Ozone in Europe in 2011, EMEP/MSC-W Status Report 1/2013, The Norwegian Meteorological Institute, Oslo, Norway, 85-104, 2013.

Simpson, D., Benedictow, A., Berge, H., Bergström, R., Emberson, L. D., Fagerli, H., Flechard, C. R., Hayman, G. D., Gauss, M., Jonson, J. E., Jenkin, M. E., Nyíri, A., Richter, C., Semeena, V. S., Tsyro, S., Tuovinen, J.-P., Valdebenito, Á., and Wind, P.: The EMEP MSC-W chemical transport model - technical description, Atmos. Chem. Phys., 12, 7825-7865, doi:10.5194/acp-12-7825-2012, 2012.

Tsyro, S., Yttri, K. E., and Aas, W.: Measurement and model assessment of particulate matter in Europe in 2010, in: Transboundary particulate matter in Europe, EMEP/MSC-W Status Report 4/2012, Norwegian Institute for Air Research, Kjeller, Norway, 22-36, 2012.

Tuovinen, J.-P., Hakola, H., Karlsson, P. E., and Simpson, D.: Air pollution risks to northern European forests in a changing climate, in: Climate Change, Air Pollution and Global Challenges: Understanding and Perspectives from Forest Research, edited by: Matyssek, R.,Cudlin, P., Mikkelsen, T., Tuovinen, J., Wieser, G., Paoletti, E., and Clarke, N., Developments in Environmental Science, Elsevier Science, 13, 77-99, doi:10.1016/B978-0-08098349-3.00005-0, 2013. 
Vinken, G. C. M., Boersma, K. F., Jacob, D. J. and Meijer, E. W.: Accounting for non-linear chemistry of ship plumes in the GEOS-Chem global chemistry transport model, Atmos. Chem. Phys., 11, 11707-11722, doi:10.5194/acp-11-117072011, 2011.
WMO: Health Risks of Particulate Matter From Long-Range Transboundary Air Pollution, Tech. rep., Bonn: World Health Organization, European Centre for Environment and Health, available at: http://www.euro.who.int/_data/assets/pdf_file/0006/78657/ E88189.pdf (last access: 11 August 2014), 2006. 